XOSÉ ARMAS CASTRO

\title{
Os arquivos municipais de Galicia e os fondos documentais da época medieval
}
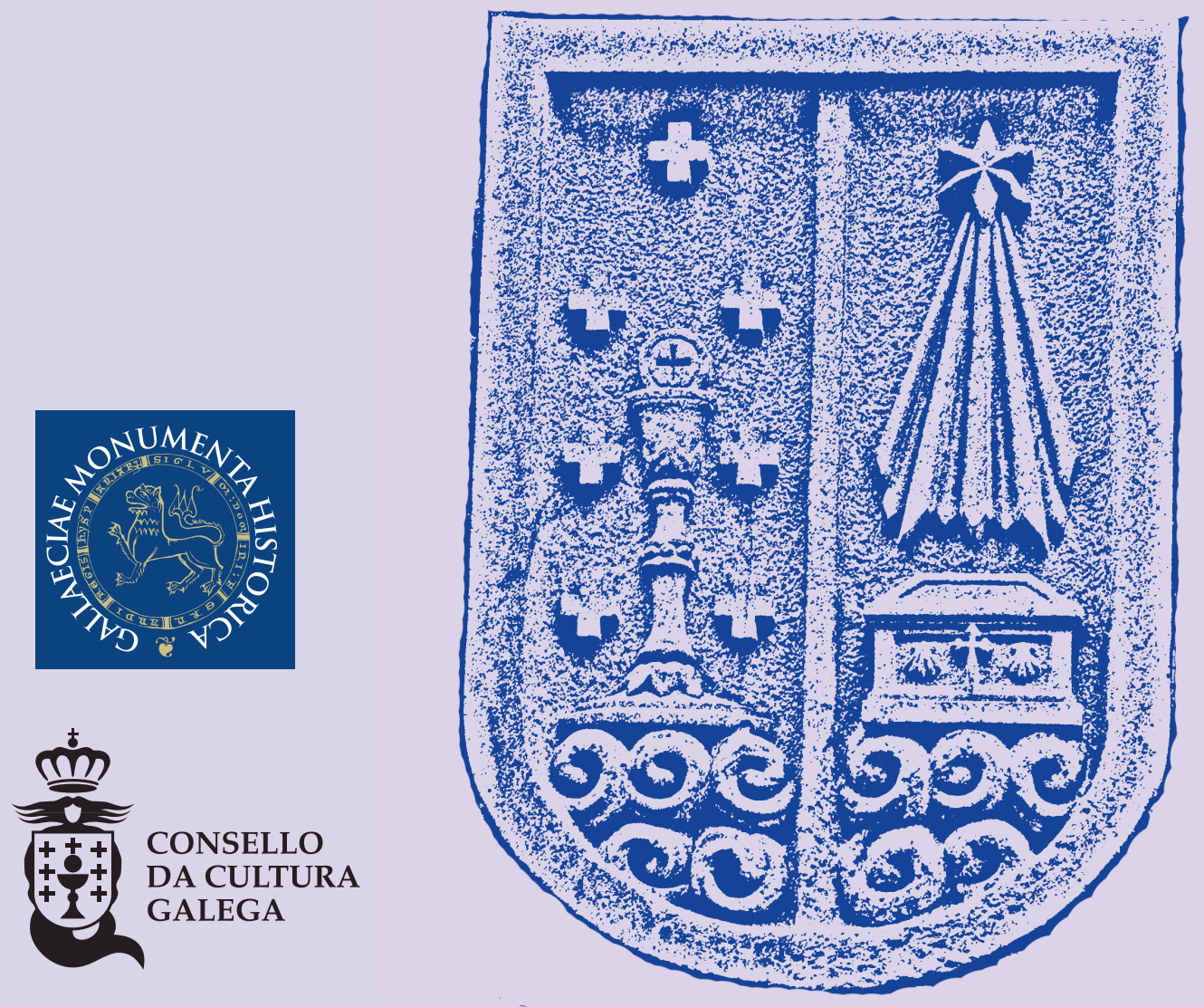
ARMas CASTRO, X.: Os arquivos municipais de Galicia e os fondos documentais da época medieval, Consello da Cultura Galega, 2014.

[Accesible en: http://gmh.consellodacultura.org/recursos/estudos/estudo/f/95/] doi.org/10.17075/gmh.002 
Os arquivos municipais de Galicia e os fondos documentais da época medieval 


\section{XOSÉ ARMAS CASTRO \\ Os arquivos municipais de Galicia e os fondos documentais da época medieval}


Os arquivos municipais naceron en Galicia, como no conxunto dos reinos peninsulares, ao mesmo tempo que os concellos urbanos. E en Galicia as vilas e cidades naceron -ou renaceron- no período que vai entre os séculos xi e xiii, froito das políticas poboadoras levadas a cabo polos poderes monárquico e señorial ${ }^{1}$.

Unha vez constituídos como entidades xurídico-políticas, os concellos pasaron a formar parte da rede de poderes feudais. Lonxe de erguer un proxecto político alternativo, como expresión dos intereses das oligarquías urbanas, acabaron buscando o seu acomodo ao lado dos poderes real e señorial. Isto é o que permite falar dos concellos como señoríos colectivos, detidos polos cabidos de rexedores, que exercían un poder de tipo señorial sobre a poboación dun termo ou alfoz máis ou menos amplo.

O exercicio do poder local por parte dos concellos determinou a necesidade de recibir, producir e custodiar escrituras de características diversas que testemuñaban a lexitimidade do poder municipal, deixaban constancia da actividade normativa e xudicial dos concellos e daban noticia das relacións co poder real, co señorial e cos particulares. Así naceron os arquivos municipais nas cidades galegas da Idade Media.

É a nosa intención facer unha aproximación xeral á formación dos arquivos municipais de Galicia e aos seus fondos documentais de época medieval. Será unha síntese necesariamente provisional mentres non dispońamos de máis

1 Para unha aproximación de conxunto ao feito urbano na Galicia medieval, pode consultarse: López Alsina (1977), Pallares (1987), Portela (1987), García Oro (1987), López Carreira (1999). As cidades que contan con monografías actualizadas sobre a época medieval son: A Coruña (Barral, 1998; Sánchez Chouza, 2005), Ourense (López Carreira, 1998), Pontevedra (Armas Castro, 1992) e Santiago (López Alsina, 1988). 
monografías sobre estes arquivos, especialmente sobre os que conservan importantes fondos documentais da época medieval ${ }^{2}$.

\section{A formación dos arquivos municipais de Galicia na Idade Media}

Desde que as vilas e cidades de Galicia reciben as cartas forais e os privilexios outorgados polos poderes real e señorial, desde que os oficiais municipais comezan a existir e a recibir os seus nomeamentos, desde que os concellos regulan os diversos ámbitos da vida urbana, comeza tamén a facerse necesario conservar as escrituras que lexitiman os privilexios urbanos e o exercicio do poder municipal.

O sistema de conservación e custodia das escrituras a que ía dando lugar a vida municipal era moi rudimentario durante a Idade Media, xa que a maior parte das vilas e cidades de Galicia non dispuxeron de casas propias do concello ata finais do século xv, o cal impedía a existencia dun local estable onde depositar as escrituras recibidas e producidas polos concellos. A práctica habitual no conxunto dos reinos peninsulares era encomendar a súa custodia aos oficiais do concello, que as gardaban como mellor podían nas súas propias casas (García Ruipérez, Fernández Hidalgo, 1999).

As normas máis antigas sobre a elaboración e depósito da documentación municipal atopámolas nas Leis de Afonso X, a mediados do século xiii. Trataban de regular o traballo dos escribáns e a elaboración de libros rexistros nos que se fosen compilando os instrumentos escritos que recibían os concellos e os que eles mesmos ían producindo. Establecían que os escribáns debían "guardar un libro registro en que escriban las notas de todas la cartas [...] y en cada villa debe haber otro registro en que escriban todas las cuentas de las rentas de su concejo para saber cuantas son» (Martínez Díez, 1985, 366 ss.). Pero a realidade tardou tempo en adaptarse a estas normas.

2 Os arquivos municipais con fondos medievais máis ricos e mellor coñecidos son o de Ourense, grazas aos traballos de Gallego (1981, 1985), e o de Pontevedra, estudado por López Gómez (1977) e Peiró (2000). Noticias dos fondos municipais medievais de Santiago e A Coruña poden atoparse en Barreiro, Portela, Pallares (1988). Tamén resultan de interese as achegas de Vázquez Bertomeu (2001) sobre a documentación notarial municipal de Santiago e Pontevedra na Idade Media. 
Os escasos datos de que dispoñemos sobre os primeiros pasos dos arquivos municipais de Galicia na Idade Media (Barreiro, 1882; Gallego, 1981, 1985; Peiró, 2000) debúxannos un panorama en que os rexedores e outros oficiais municipais custodian nas casas particulares, en sacos e caixas, os «privilexios e outras escrituras» do concello. O avance máis relevante que se produciu na Idade Media foi a habilitación dunha «arca» ou "hucha» do concello na que se almacenaban, sen demasiada orde, privilexios municipais, cédulas reais e algúns outros papeis soltos.

A primeira noticia que nos desvela a existencia dunha práctica sistemática de conservación e custodia da documentación municipal nos concellos galegos data do ano 1419 e relata como, reunido o concello de Santiago nas casas do notario municipal Ruy Martines, o rexedor compostelán Martín Galos, actuando de seu e en nome do rexedor Pero Yanes Abraldes, entrega ao concello para a súa confirmación polo monarca Xoán II «dous privilegios escriptos en pergamino e bulados con seelo de plomo [...] os quaes privilegios estavan enna ucha que eles teen por lo dito conçello en que jazen as escrituras que perteeçen ao dito conçello» ${ }^{3}$. Semella unha práctica habitual do concello de Santiago, á altura do primeiro terzo do século XV, gardar os privilexios e outras escrituras de interese para a cidade nunha «hucha do concello», que estaba depositada nas casas do rexedor máis antigo.

De xeito semellante actuaba o concello de Ourense, aínda que aquí dispoñemos de datos máis precisos e detallados. No ano 1434, o concello, reunido na casa do rexedor Loys Gonçalves, entrega ata 16 privilexios e escrituras en pergameo para que se garden «ena arca do conçello». A tal arca estaba pechada con tres chaves, que se entregaron ao procurador do concello e a dous rexedores, respectivamente, coa condición «que se non abrise sen estar todos tres presentes e o notario do concello» ${ }^{4}$. Unha medida encamiñada a garantir unha maior seguridade das escrituras, pońendo fin ao libre acceso dos oficiais do concello aos documentos municipais, unha situación que ocasionaba frecuentes subtraccións e extravíos.

3 Acordo do concello de Santiago de data 1419/novembro/10. Publica Rodríguez González (1992), f. 68v .

4 Escritura de data 1434/decembro/21, procedente do Arquivo Histórico Provincial de Ourense e publicada por Ferro Couselo (1967), vol. II, 21, pp. 28-31 da edición facsimilar de 1996. 
A mediados do século xv o arquivo municipal ourensán, aínda dentro da elemental organización que levamos descrito, gardaba, xunto coas escrituras orixinais, algunha forma de rexistro destas e o selo municipal, símbolo da capacidade xurídica do concello e garantía da autenticidade dos documentos que expedía. No ano 1451, con motivo da morte do rexedor Gomes de Chantada, depositario das escrituras e do selo do concello, presentábanse no seu domicilio o xuíz, catro rexedores, o procurador e o notario do concello para «requerir» á súa viúva, Aldonça de Aguiar, a entrega dos instrumentos do arquivo municipal. A viúva fixo entrega ao concello dunha longa relación de escrituras, xunto cun rexistro delas, gardadas nun saco, e o selo do concello metido nunha caixa. Rexistro, escrituras orixinais e selo eran entregados polo concello ao xuíz da cidade, Afonso Yanes da Lagea, para a súa custodia ${ }^{5}$.

Unha desorde semellante debía existir nas demais vilas e cidades galegas ao longo do século XV en canto á custodia da documentación municipal, o que xustificaba que no ano 1491 o concello de Mondońedo establecese, por medio dunha ordenanza, "que de aquí adelante el dicho conzejo tubiese Arca, que se llamase Arca de Conzejo, en la qual tubiesen y metiesen las escripturas y cosas tocantes al dicho conzejo, porque no andubiesen de mano en mano y se perdiesen, como fasta aquí andaban». A arca debía estar pechada con dúas chaves «de diverso ser», que se entregarían: unha ao procurador e a outra aos rexedores. $\mathrm{Na}$ arca debían estar depositadas as escrituras do concello, un inventario ou memorial destas e «as outras cousas» ${ }^{6}$.

Podemos concluír que, durante a Idade Media, a documentación dos concellos galegos debeu sufrir un errático periplo polas casas dos oficiais municipais, entre os que os rexedores e o notario semellan ter un papel máis relevante. $\mathrm{O}$ libre acceso dos oficiais municipais ás escrituras e a utilización dos orixinais en preitos e actos probatorios debeu dar lugar e frecuentes extravíos. A fórmula adoptada para remediar estes males foi a adquisición dunha arca -ou hucha- do concello na que se gardaban, baixo diversas chaves, escrituras, rexistros destas e os demais instrumentos duns incipientes arquivos municipais. Esta realidade

5 Escritura de data 1451/maio/18, publicada en Idem, vol. II, 44, pp. 54-55.

6 Ordenanzas de 1491 conservadas en copia do século XVIII no Arquivo Municipal de Mondoñedo. Publica López Alsina (1977), p. 144. 
respondía de forma coherente a unha fase da historia dos arquivos na que se concibían como almacéns de escrituras, que debían servir para probar os privilexios e liberdades municipais nos numerosos preitos que enfrontaban aos concellos cos poderes señoriais e cos particulares.

Foi a finais do século xv e comezos do xvi cando se produciu un cambio cualitativo na organización dos arquivos municipais, como unha manifestación máis dos cambios político-administrativos que configuraron o Estado moderno. En 1480, os Reis Católicos, dentro dun programa para instalar un novo réxime municipal integrado nas estruturas do Estado centralizado, ordenaron que os concellos tivesen casas propias onde realizar os seus axuntamentos e asentar a vida municipal ${ }^{7}$. Entre a última década do século $\mathrm{XV}$ e as primeiras do xvi os concellos de Galicia acabaron erguendo as primeiras casas consistoriais, o que facilitou asentamentos estables para os arquivos municipais e puxo fin, pouco a pouco, á dispersión da documentación polas casas dos oficiais dos concellos.

As normas dos monarcas católicos tamén se ocuparon da adecuada conservación da documentación municipal e para iso elevaron á categoría de norma o que viña sendo costume nos concellos máis avanzados. Nunha Real Pragmática de 1500 establecían: «que hagan arca donde estén los privilegios y escrituras del Concejo a buen recaudo, que a lo menos tengan tres llaves, que la una la tenga la Justicia, y la otra uno de los regidores, y la otra el escribano del Concejo, de manera que no se puedan sacar de allí» ${ }^{8}$.

Unha vez regulado o edificio e a arca municipal, quedaba promover certa orde na xestión da documentación. Unha nova Pragmática prescribía, en 1501, que se ordenasen as escrituras en libros e que se fixesen índices das que contiñan. Concretamente establecíase que houbese dous libros. Un, en papel, debía compilar «todas las cartas y ordenanzas [...] albalaes y cédulas que en los dichos cabildos fuesen presentadas». O outro, en pergameo, debía recoller «todos los

7 Novísima Recopilación de las Leyes de España. Madrid, 1976 (edición facsimilar), Tomo II, Libro VII, Título II, Ley 1: «Ennoblézcanse las ciudades y villas en tener casas grandes y bien fechas en que hagan sus ayuntamientos y concejos y que se ayunten las justicias y regidores y oficiales a entender en las cosas cumplideras a la república que han de gobernar».

8 Novísima Recopilación, cit. Tomo II, Libro VII, Título II, Ley 2. Real Pragmática dada en Sevilla o 9 de xuño de 1500 . 
privilegios que las dichas ciudades y villas y sus tierras tienen, y todas las sentencias que en su favor se han dado»?

Estas normas, aínda que foron atopando un lento cumprimento nas vilas e cidades de Galicia, acabaron producindo un efecto beneficioso sobre a conservación e ordenación da documentación municipal da Idade Media e, sobre todo, facilitaron que as series documentais comezasen a ser máis completas e ordenadas a partir do século xvi. De feito, temos constancia de que o cumprimento das pragmáticas reais sobre a organización dos arquivos municipais aínda seguía provocando protestas e denuncias nos concellos de Pontevedra, Ourense e Santiago a mediados do século XVI ${ }^{10}$, pero estas normas acabaron pońendo orde na conservación e organización da documentación e supuxeron a entrada dos arquivos municipais na etapa moderna.

\section{Os fondos documentais municipais de época medieval}

O inventario máis amplo realizado ata a actualidade sobre as fontes documentais da Galicia medieval (Barreiro, Portela, Pallares, 1988) debuxa un panorama que sitúa a Galicia entre as comunidades españolas mellor documentadas para a época medieval. Nesta radiografía, con todo, os núcleos urbanos achegan tan só un $6 \%$ da masa documental, mentres que unha amplísima maioría -algo máis do 93\%-é de procedencia eclesiástica. Isto non impide que algúns núcleos urbanos poidan considerarse afortunados en canto a cantidade e calidade da documentación conservada, especialmente Ourense e, a pouca distancia, Santiago e Pontevedra.

Ao problema da escaseza hai que engadir a dificultade para definir o que se entende por documentación municipal. Durante a Idade Media, por exemplo, o arquivo municipal identificábase co arquivo de privilexios, tamén chamado secreto, que contiña os foros, privilexios, cédulas reais e concesións señoriais de que facían gala as cidades. Chama a atención que en ningún dos rexistros documentais da época medieval se faga referencia a pezas tan xenuinamente municipais como as actas das reunións do concello, os padróns de habitantes, os repartimen-

9 Idem, Tomo II, Libro VII, Título II, Ley 3. Real Pragmática dada en Granada o 3 de setembro de 1501.

${ }^{10}$ Datos sobre preitos e reclamacións para que se cumprisen as pragmáticas sancións nos concellos de Pontevedra, Ourense e Santiago, en Peiró (2000), Gallego (1985) e Barreiro (1882). 
tos con fins fiscais, ou as contas de ingresos e gastos dos concellos. A razón deste sorprendente silencio -e motivo ao mesmo tempo da rareza dos exemplares conservados- é que esta documentación formaba parte dos arquivos dos notarios e doutros oficiais, que a gardaban nas súas casas, sufrindo así continuos avatares e perdas. Un terceiro problema que ter en conta é a dispersión dos fondos documentais municipais. Debido a que os concellos de Galicia se viron sometidos a unha forte dependencia dos poderes señorial e real, unha parte importante da documentación que regula a vida municipal foi parar aos arquivos episcopais, aos da Coroa e aos doutras institucións, como os museos provinciais, nacidos no século xix para promover os estudos locais.

Algunhas circunstancias resultaron especialmente prexudiciais para a conservación do patrimonio documental municipal da época medieval e acabaron dando lugar a perdas irreparables. Referirémonos aquí a tres acontecementos de características ben diferentes, pero de resultados igualmente negativos.

En primeiro lugar, os acontecementos que conforman a Revolta Irmandińa, que tivo nas cidades e vilas galegas os seus centros de operacións, e que deron lugar a destrucións de escrituras dos arquivos municipais que podían ser utilizadas para tomar represalias unha vez finalizado o conflito, como se pode deducir do elocuente silencio que gardan as series documentais municipais -alí onde existen-para as décadas de 1460 e 1470.

Outro tipo de acontecementos responsables da perda de documentación foron os incendios, que, fortuítos ou intencionados, eran habituais nuns núcleos urbanos con edificios especialmente sensibles ás chamas. $\mathrm{O}$ mellor coñecido e o que afectou ao arquivo municipal de Santiago no ano 1559. Con motivo da reparación das casas consistoriais, a arca que gardaba as escrituras do concello trasladouse á casa do rexedor Fructuoso Galos, onde sufriu os efectos dun incendio do que Bernardo Barreiro lamenta especialmente "los libros de actas consistoriales perdidos». Para facer reparación dos danos sufridos, no ano 1576 habilitouse un novo espazo nos baixos das casas consistoriais - sitas na zona alta da Quintana, ao lado do mosteiro de San Paio de Antealtares-, designado como «escriptorio y archivio público de la dicha ciudad» (Barreiro, 1882), pero as perdas dunha parte da documentación xa eran irreparables.

Por último, as confrontacións políticas que se produciron ao longo do século xix no ámbito municipal, especialmente con motivo dos intentos de demo- 
cratizar a vida local durante a Revolución de 1868, deron lugar tamén á destrución de fondos documentais por parte dos bandos en liza: unha circunstancia á que Olga Gallego (1988) atribúe a desaparición dunha boa parte do arquivo municipal de Ribadavia.

A documentación municipal de época medieval que chegou ata a actualidade, aínda que sexa unha parte da que os concellos recibiron e produciron ao longo da Idade Media, constitúe un patrimonio cultural valiosísimo e un recurso imprescindible para o coñecemento da formación dos núcleos urbanos galegos e do réxime municipal. Para realizar unha aproximación sistemática a este patrimonio documental, servirémonos dos traballos de catalogación realizados nos diferentes arquivos municipais así como das monografías que prestan atención preferente a estes fondos documentais. E comezaremos distinguindo entre a documentación recibida polos concellos, procedente das chancelarías real e señorial ou doutras institucións, por unha parte, e a emitida polos propios concellos, pola outra.

\section{a) Documentación recibida polos concellos}

É a documentación municipal máis antiga, a que dá carta de natureza aos núcleos urbanos e pon en marcha a vida municipal. Trátase, sobre todo, de cartas forais e privilexios procedentes das chancelarías real e señorial, e doutros documentos diversos en que nobres, mosteiros ou particulares disputan cos concellos sobre determinados dereitos ou costumes antigos. Esta documentación foi a que recibiu máis atención e a que concitou maiores esforzos de conservación por parte dos concellos. Os arquivos municipais, nas súas orixes, teñen como razón de ser a preservación destes documentos.

\section{Cartas forais e privilexios}

Todas as vilas e cidades conservaron as cartas de poboación e os privilexios outorgados por monarcas e señores para exhibilos como proba dos seus dereitos e liberdades, e puxeron empeño en obter as confirmacións por parte dos sucesivos monarcas ou señores para manter a súa vixencia. Esta insistencia dos concellos en confirmar os privilexios foi o que permitiu conservar algunhas destas 
pezas, xa que os orixinais perdéronse, en moitos casos, e coñecémolas grazas ás confirmacións ou traslados posteriores.

Os foros fundacionais da maior parte das vilas e cidades galegas son escrituras breves nas que os monarcas ou señores recoñécenlles aos habitantes que poboan a localidade unha serie de privilexios, libéranos de determinadas cargas feudais e concédenlles un réxime xurídico especial. Estas escrituras fundacionais fóronse completando con novos privilexios que facían referencia á práctica en exclusiva de determinadas actividades, ao dereito de realizar feiras ou á capacidade de designar os propios xuíces.

Estas coleccións de foros e privilexios municipais resultan hoxe ben coñecidos grazas ao labor de compilación e edición levado a cabo por unha ilustre xeración de arquiveiros e historiadores galegos a finais do século xix e na primeira metade do XX. Só por lembrar os exemplos máis emblemáticos, citaremos os foros municipais de Santiago e a súa Terra, estudados por López Ferreiro (1895), os de Ourense, editados por Martínez Sueiro (1912), os privilexios reais de Pontevedra, compilados por Fernández Villamil (1942), ou os da Coruña, estudados por Vedía y Gossens (1845) e, máis recentemente, por Martínez Barbeito (1980) e González Garcés (1987). Aínda así, esta rica serie de cartas fundacionais e privilexios están á espera de seren compilados, editados de forma adecuada e estudados sistematicamente para reinterpretar o proceso de fundación e desenvolvemento dos núcleos urbanos galegos durante a Idade Media.

\section{Outras escrituras: pedidos, demandas, executorias, sentenzas...}

Incluímos aquí unha gran variedade de documentos procedentes das instancias rexia ou señorial, pero tamén de mosteiros, membros da nobreza ou particulares que lles demandan aos concellos o cumprimento de certas obrigas ou costumes que os beneficiaban.

Trátase, na maior parte dos casos, de pedidos e outras figuras fiscais que reclaman os monarcas e señores como principais perceptores de rendas nos núcleos urbanos, pero tamén de escrituras en que mosteiros e membros da nobreza territorial esíxenlles aos concellos dereitos e rendas que lles correspondían, real ou supostamente, por concesión rexia ou por costume. Tamén incluímos aquí as escrituras que se fan eco das demandas realizadas por grupos socio-profesionais 
ou particulares para que se lles respecten usos, costumes e ordenanzas que regulaban prácticas antigas ou dereitos que os asistían.

A maior parte destas escrituras non se conservaron nos arquivos municipais na súa forma orixinal, senón copiadas polos notarios nos libros de actas dos concellos ou inseridas nos preitos en que se dilucidaron as correspondentes demandas.

\section{b) Documentación emitida polos concellos}

O exercicio do poder municipal daba lugar a unha abundante e variada documentación que era escriturada polos notarios dos concellos, cargo de designación rexia ou señorial que recaía nun dos notarios de número das vilas e cidades. Os notarios municipais desempeñaban o cargo de forma vitalicia (polo menos nos últimos séculos da Idade Media), percibían un salario a cargo da facenda municipal e tiñan como obrigas propias do cargo: asistir ás reunións do concello, asentar no libro de actas todos os acordos tomados polo cabido de rexedores, redactar os documentos de titularidade municipal e usar ben e lealmente o oficio.

Seguindo os criterios habituais para a clasificación da documentación de orixe municipal (Pino Rebolledo, 1991), distinguiremos entre documentos de réxime interno, que se ocupan de todo o relacionado coa administración interna dos concellos, e documentos de relación con outras instancias de poder ou con particulares. Os documentos de réxime interno constitúen os fondos máis numerosos e emblemáticos dos producidos polos concellos. Entre eles podemos destacar: as actas capitulares, os nomeamentos e tomas de posesión dos oficiais municipais, os libramentos e ordes de pago e as cartas de rendición de contas presentadas anualmente polos procuradores do concello. Entre os documentos de relación do concello con outras instancias podemos mencionar: as cartas de veciñanza, os padróns e repartimentos fiscais, as ordenanzas que regulaban os diferentes ámbitos da vida urbana, ou os pregóns dos acordos que tiñan unha especial incidencia na poboación. Faremos algunhas consideracións sobre os tipos documentais máis emblemáticos e que proporcionan datos máis relevantes para a historia urbana medieval. 


\section{Actas capitulares ou "Libros do concello"}

Desde o punto de vista documental, son a espiña dorsal da vida municipal, xa que conteñen o rexistro escrito, redactado polo notario do concello, dos acordos adoptados no axuntamento do cabido de rexedores cos oficiais do concello. O feito de que as actas acabasen sendo compiladas en forma de libro é o que xustifica a súa denominación como «Libro do concello» ou «Libro de notas do concello». En realidade, non son un rexistro completo e detallado dos acordos das sesións do concello, senón notas breves que dan conta do acordado, o que os asemella formalmente aos libros de notas ou minutas dos notarios. A función destas actas capitulares era dobre: por unha parte, deixar constancia escrita dos acordos tomados e, por outra, servir de matriz para expedir documentos oficiais a partir das notas tomadas nas sesións consistoriais. Isto é o que explica que aparezan anotacións nas marxes do estilo de «feita e dada a», «por esta nota se ha de faser o auto", etc. Un valor engadido das actas capitulares é a inserción do texto íntegro de cartas dirixidas aos concellos polos monarcas, os señores ou particulares, o que nos permite coñecer escrituras que non se conservan no seu formato orixinal e que se terían perdido se non quedasen incorporadas nos libros de actas. Actualmente só conservamos libros de acordos dos concellos de época medieval de tres cidades -Ourense, Santiago e Pontevedra- e cronoloxicamente abranguen unha parte do século xv.

Ourense é, a gran distancia, a cidade que dispón de series máis extensas de acordos do concello do século XV. Ata un total de 6 libros, que suman cerca de 870 folios, cobren de forma razoable o período que vai entre 1432 e 1460 (Gallego, 1985). Os asuntos que tratan son todos os que ocupaban a atención das reunións do concello: nomeamento e toma de posesión de oficiais municipais, cartas de veciñanza, conservación e limpeza das rúas e espazos públicos, obras da Ponte e barca do río Miño, recadación de impostos, cartas de pago por servizos prestados ao concello, ordenanzas sobre abastecemento, funcionamento do mercado e diferentes oficios, sobre os xudeus que habitaban na cidade, sobre a Irmandade, e unha longa lista que non podemos detallar aquí. Algunhas destas actas foron publicadas por primeira vez por Ferro Couselo (1967) e os datos que proporcionan constitúen un soporte fundamental do estudo de López Carreira (1998) sobre Ourense no século XVI. A importancia destes libros de 
actas para o coñecemento da vida municipal na Idade Media demanda unha edición adecuada que pońa ao alcance dos estudosos esta rica fonte documental.

$\mathrm{O}$ arquivo municipal de Santiago conserva un «Libro do concello» que, en 96 folios, recolle os acordos dos consistorios realizados entre os anos $1416 \mathrm{e}$ 1422. O caso deste libro pode resultar ilustrativo da azarosa vida da documentación municipal. Seguramente era un dos primeiros dunha serie de libros que debía cubrir todo o século xv e foi o único que sobreviviu á incuria dos responsables da documentación durante a Idade Media, aos incendios que afectaron ao arquivo do concello en 1559 e 1761, e a outros avatares que sufriron os fondos documentais municipais. Encadernado seguramente no século xviii, estivo desaparecido do arquivo durante o século xix, probablemente por ser prestado a alguén que non se ocupou de retornalo ao seu lugar orixinal. Finalmente, foi devolto ao arquivo municipal, no ano 1967, pola familia compostelá Pintos Cea, nunha encomiable mostra de respecto e aprecio do patrimonio documental. Utilizado nos seus estudos composteláns por B. Barreiro de Vázquez Varela, A. Neira de Mosquera e A. López Ferreiro, finalmente foi publicado polo Consello da Cultura Galega, segundo transcrición e estudo de A. Rodríguez González (1992). O seu contido é o propio dos libros de actas capitulares: nomeamento e toma de posesión de cargos municipais, repartimentos de tallas, pedidos, alcabalas e outros impostos, ordes e cartas de pago, cartas de poder a favor de diferentes oficias do concello, rendición de contas de ingresos e gastos por parte dos procuradores municipais, ordenanzas sobre o abastecemento da cidade, normas sobre o funcionamento do mercado e dos oficios, sobre conservación das murallas e as portas da cidade, sobre a Irmandade, etc.

$\mathrm{O}$ arquivo municipal de Pontevedra tamén debeu contar cunha ampla serie de libros de actas do concello do século xv, dos que hoxe só se conservan dúas mostras. O primeiro consiste nun «caderno de 16 follas de papel» que se conservaba no Arquivo de Castrelos (Vigo), entre os papeis da Casa de Valladares; foi copiado por Casto Sampedro en 96 cuartillas, que hoxe se conservan no Museo de Pontevedra, e recolle as actas municipais dos anos 1431 e $1432^{11}$. O outro, tamén conservado no Museo de Pontevedra, consiste nun libro de 113

\footnotetext{
${ }^{11}$ Museo de Pontevedra, Col. Sampedro, Caixa 89/2. Publica Rodríguez González (1989), pp. 49-69.
} 
folios en papel encadernados en pergameo, que abrangue as actas das reunións do concello entre 1437 e $1463^{12}$. Conservados e utilizados nos seus traballos por membros da Sociedade Arqueolóxica de Pontevedra, especialmente por Casto Sampedro e Celso García de la Riega, foi publicado polo Museo de Pontevedra, segundo transcrición e estudo de A. Rodríguez González (1989) cunhas observacións codicolóxicas de I. Millán. O contido das actas municipais de Pontevedra é moi semellante ao dos outros libros de concellos que xa analizamos, tan só queremos destacar como particularidades pontevedresas a atención prioritaria dedicada a todo o relativo á recadación de tallas, pedidos e servizos do rei e dos arcebispos composteláns, a inclusión de varios repartimentos fiscais especificando as rendas que se debían recadar en cada unha das rúas da cidade, o papel activo das confrarías dos oficios nas reunións do concello, ou o pacto de protección e axuda mutua que concertan, en 1444, o concello e Suero Gómez de Soutomaior para facer fronte á situación de inseguridade e tumultos na que estaba sumida a vila.

\section{Padróns e repartimentos fiscais}

Son documentos que nacen a partir dunha petición fiscal, habitualmente realizada polos monarcas ou os señores - menos frecuentemente polo propio concello- para facer fronte a determinados gastos. En esencia, trátase dun mandato realizado aos oficiais responsables da recadación para que realicen a derrama e procedan a recadar os impostos entre os veciños. Esta documentación resulta especialmente elocuente cando ofrece relación detallada da contribución que lle toca a cada veciño (fogar) na correspondente derrama, engadindo, ás veces, algúns datos complementarios sobre estado civil, profesión ou condición económica. Aínda tendo en conta que estes padróns e repartimentos de impostos son realizados con fins fiscais e conteñen ocultacións e terxiversacións, constitúen un instrumento fundamental para aproximarnos ao continxente de poboación e á estrutura socio-profesional dos habitantes das cidades galegas a finais da Idade Media.

\footnotetext{
12 Museo de Pontevedra, Colección Sampedro, Caixa 2/1. Publica Rodríguez González (1989).
} 
Ourense volve ser a cidade que ofrece series de padróns e repartimentos máis continuas que cobren, de forma desigual, desde o ano 1428 ata finais do século xv. Algúns destes padróns aparecen incluídos nos libros do concello aos que nos referimos máis arriba, pero outros atópanse como cadernos soltos na Sección de Papeis do Concello do Arquivo Histórico Provincial de Ourense. Unha parte reducida destes foi publicada por Ferro Couselo (1967) e, recentemente, trinta destes padróns foron editados polo Consello da Cultura Galega segundo transcrición e estudo de López Carreira (1995).

Santiago e Pontevedra tamén realizaron padróns e repartimentos de forma habitual, como se desprende dos acordos que se recollen nos respectivos libros do concello, pero en ningunha das dúas cidades conservamos relacións nominais de veciños ata as primeiras décadas do século xvi. Para A Coruña, Sánchez Chouza (2005) localizou no Archivo de la Real Chancillería de Valladolid un Padrón e Repartimento do ano 1496 que recolle, rúa a rúa, os veciños que pagaban pedidos para a Irmandade ${ }^{13}$.

A existencia destes padróns e repartimentos fiscais permítenos achegarnos, xunto con outras aproximacións complementarias, e coas precaucións necesarias para todo o relacionado coas pescudas demográficas para o período medieval, ao número de veciños ou fogares dos que dispoñían as vilas e cidades galegas a finais da Idade Media. Pontevedra superaba os 1000 veciños (arredor de 5000 habitantes), Santiago e A Coruña debían estar próximas a esta cifra (para A Coruña constan algo máis de 900) e o resto das cidades e vilas, como Ourense, Tui ou Mondoñedo, non debían alcanzar os 300 veciños na última década o século XV.

\section{Ordenanzas}

As ordenanzas - ordenaçoes na documentación medieval- eran normas aprobadas polos concellos, ás veces polos señores, e máis frecuentemente por ambos os dous á vez, que regulaban os prezos de venda das mercadorías cun maior volume de negocio no mercado urbano: viño, peixe, carne, pan... e tamén os pesos e medidas polas que debía venderse na cidade. Outras ordenanzas facían

13 Padrones y Repartimientos para la Hermandad hechos en A Coruña en el año de 1496. Archivo de la Real Chancillería de Valladolid, Sala de Hijosdalgo, atado 475, exp. 17. Vid. Sánchez Chouza (2005), pp. 30 e ss. 
referencia á elección e duración dos cargos municipais ou ao funcionamento de determinados oficios que xeraban maior actividade nas cidades: carniceiros, zapateiros, panadeiros, carpinteiros, ferreiros... e ás rendas e posturas que lle correspondían ao concello.

Unha parte destas ordenanzas aparecen incluídas nos libros de actas dos concellos e outras foron copiadas en cadernos separados formando parte doutras seccións dos arquivos municipais. Todas incluían ao final a indicación de que fosen pregoadas polas prazas da cidade para asegurar o seu cońecemento polo común dos veciños.

Son abundantes e variadas as mostras de ordenanzas da Idade Media conservadas para as diferentes vilas e cidades. Faremos referencia só ás que resultan mellor cońecidas. As que se inclúen nos libros do concello de Ourense fan referencia a funcionamento de diferentes oficios da cidade e foron parcialmente publicadas por Ferro Couselo (1967). As do libro do concello de Santiago, dos anos 1417 e 1418, tratan sobre os prezos de venda de diversos productos no mercado, sobre os salarios que debían percibir pedreiros e carpinteiros en xornadas de verán e de inverno, ou sobre as normas que debían seguir os prateiros no desenvolvemento do oficio de pratería ${ }^{14}$. As da cidade de Pontevedra, dos anos 1432 e 1496, reproducían as "posturas e ordenanças antigas» que regulaban ata os máis pequenos detalles do funcionamento do mercado, da venda de mercancías e das rendas que debía percibir o concello ${ }^{15}$. E, para rematar, citaremos as ordenanzas da vila de Mondońedo, das que se conserva unha serie relativamente extensa dos anos 1316, 1491 e $1493^{16}$.

\section{Notas e minutas notariais}

En todas as cidades e vilas galegas había, a finais da Idade Media, unha nómina reducida de «notarios de número» que escrituraban todo tipo de contratos e instrumentos escritos que se realizaban entre particulares. Un deles era nomeado notario do concello para deixar constancia escrita de todas as actuación

\footnotetext{
14 Publicadas por Rodríguez González (1992), fols. 23-23v, 29-30v e 49v-50.

15 Publicadas por Armas Castro (1992), pp. 335-336 e 382-388.

16 Publicadas por López Alsina (1977), pp. 137-150.
} 
municipais. Este carácter entre público e privado do oficio de notario na Idade Media é o que xustifica que nos arquivos notariais se conserven escrituras que fan referencia directa á vida municipal e que, en sentido inverso, se conserven nos arquivos municipais notas e minutas dos notarios, que proporcionan información moi valiosa para o cońecemento da vida urbana a finais da Idade Media.

Os restos conservados de notas e minutas notariais do século xv son escasos, pero resultan dunha gran riqueza, xa que recollen todo tipo de contratos que se realizaban entre os veciños e tamén por parte da institución municipal.

$\mathrm{O}$ arquivo municipal de Ourense conserva varios restos de notas notariais de finais do século $\mathrm{xv}$, das que as máis amplas son as que compoñen o Registro de notas de Juan García, do ano 1484. Nos seus 327 folios, recolle todo tipo de escrituras realizadas polo bispo de Ourense e por particulares, traslados de documentos reais e escrituras do concello. Algunhas destas escrituras foron publicadas por Ferro Couselo (1967) e, máis recentemente, López Carreira (1993) fixo unha rexesta e reproduciu algúns dos documentos íntegros.

O Museo de Pontevedra e o Arquivo Histórico Provincial de Pontevedra tamén conservan algúns restos de notas de diferentes notarios de finais da Idade Media, entre os que destacaremos, polo seu interese, dous destes libro. O primeiro pertence ao notario do concello Pedro Fiel e recolle unha serie de escrituras, entre as que se encontran varios contratos de foro de bens propios do concello e algúns traslados de ordenanzas municipais que van entre os anos 1489 e $1543^{17}$. O outro é un libro de notas dos notarios Lourenzo Eanes e Juan Afonso, que recolle, en 68 folios, todo tipo de contratos entre os vecińos de Pontevedra realizados entre os anos 1433 e $1435^{18}$ : cartas de recońecemento e obriga, cartas de poder, contratos de aprendizaxe de oficios, contratos de frete entre mercadores, compravendas e foros de bens urbanos e, por citar un documento excepcional, un contrato de perdón dun esposo agraviado á súa dona, que cometera adulterio. Este minutario ou libro de notas foi publicado polo Consello da Cultura Galega segundo transcrición e estudo de Rodríguez González e Armas Castro (1992).

Estas páxinas non recollen a cantidade e variedade dos fondos documentais medievais conservados nos arquivos municipais de Galicia. Non era a nosa

\footnotetext{
${ }^{17}$ Museo de Pontevedra, Colección Sampedro, Caixa 2/2.

${ }^{18}$ Museo de Pontevedra, Colección Sampedro, Caixa 2/5.
} 
intención facer un inventario detallado deste. Só intentamos relatar as peripecias que seguiu a documentación medieval de orixe municipal ata chegar á actualidade, e debuxar un cadro en que destacasen as tipoloxías documentais que resultan máis emblemáticas e que ofrecen maiores posibilidades de aproveitamento para o estudo dos núcleos urbanos medievais galegos.

\section{Bibliografía}

Armas Castro, J.: Pontevedra en los siglos XII a XV. Configuración y desarrollo de una villa marinera en la Galicia medieval, A Coruña, Fundación «Pedro Barrié de la Maza, Conde de Fenosa», 1992.

Barral, D.: La Coruña en los siglos XIII al XV, A Coruña, Fundación «Pedro Barrié de la Maza, Conde de Fenosa», 1998.

Barreiro Fernández, X. R. (coord.), E. Portela e M. C. Pallares (dirs.): Inventario das fontes documentais da Galicia medieval, Santiago de Compostela, Consello da Cultura Galega, 1988.

Barreiro de VÁzQuez Varela, B.: «Archivo de la ciudad de Santiago: el incendio de 1559", La Ilustración Cantábrica, t. 4, n.o 7 (1882), pp. 74-75.

Fernández Villamil, E.: "Privilegios reales del Museo de Pontevedra», El Museo de Pontevedra, tomo I (1942), pp. 31-56, 79-106, 132-174.

Ferro Couselo, X.: A vida e a fala dos devanceiros. Escolma de documentos en galego dos séculos XIII ao XVI, Vigo, Galaxia/Fundación Penzol, 1996 [1967]. Edición facsimilar.

Gallego, O.: "El archivo del concejo de la ciudad de Orense", Boletín Auriense, XI (1981), pp. 177-194.

— «El archivo del concejo de la ciudad de Orense y sus fondos hasta 1600», en La ciudad hispánica durante los siglos XIII al XVI, Madrid, Universidad Complutense, 1985, pp. 183-206.

— «El ayuntamiento de Ribadavia. Un caso de destrucción de archivo municipal», en I Congreso de Archiveros y Bibliotecarios de la Administración Local, Valencia, Generalitat, 1988, pp. 21-46.

García Oro, J.: Galicia en los siglos XIV y XV. II Galicia urbana, A Coruña, Fundación «Pedro Barrié de la Maza, Conde de Fenosa», 1987. 
García Ruipérez, M. e M. C. Fernández Hidalgo: Los archivos municipales en España durante el Antiguo Régimen, Cuenca, Universidad de Castilla-La Mancha, 1999.

GonzÁlez Garcés, M.: Historia de La Coruña. Edad Media, A Coruña, Caixa Galicia, 1987.

LÓPEZ Alsina, F.: Introducción al fenómeno urbano medieval gallego, a través de tres ejemplos: Mondoñedo, Vivero y Ribadeo, Santiago de Compostela, Universidade, 1977.

- La ciudad de Santiago de Compostela en la Alta Edad Media, Santiago, Concello de Santiago, 1988.

López Carreira, A.: «De Ourense medieval. Rexistro de Xoán García, Notario do Concello de Ourense, do ano 1484», Boletín Auriense, Anexo 17 (1993).

- Padróns de Ourense do século XV, Santiago de Compostela, Consello da Cultura Galega, 1995.

- A cidade de Ourense no século XV, Ourense, Deputación Provincial, 1998.

- A cidade medieval galega, Vigo, Promocións Culturais Galegas, 1999.

López Ferreiro, A.: Fueros municipales de Santiago y su Tierra, Madrid, Ediciones Castilla, 1975 [1895]. Edición facsimilar.

López Gómez, P.: Archivo Histórico Provincial de Pontevedra. Guía del investigador, Pontevedra, MEC/Deputación Provincial de Pontevedra, 1977.

Martínez Barbeito, I. et al.: Privilegios reales y viejos documentos de La Coru$\tilde{n} a$, Madrid, Joyas Bibliográficas, 1980.

Martínez Díez, G.: Las Leyes de Alfonso X. Edición y análisis crítico, Ávila, Fundación Sánchez Albornoz, 1985.

Martínez Sueiro, M.: Fueros municipales de Orense. Separata do Boletín de la Comisión Provincial de Monumentos de Orense, 1978 [1912]. Edición facsimilar.

PALLARES, M. C.: «Sistema feudal y proceso de urbanización: algunas reflexiones a propósito del caso gallego en los siglos XII y XIII», en Jubilatio, vol. 1, Santiago de Compostela, Universidade, 1987, pp. 95-105.

PeIró, M. N.: "El archivo municipal de Pontevedra. Noticias sobre su origen y organización”, Cuadernos de Estudios Gallegos, XLVII, n. ${ }^{\circ} 112$ (2000), pp. 133-145.

Pino Rebolledo, F.: Tipología de los documentos municipales (siglos XII-XVII), Valladolid, Asociación para la Defensa y Conservación de los Archivos, 1991. 
PORTELA, E.: «Sistema feudal y proceso de urbanización: las ciudades de Galicia ante la crisis bajomedieval», en Jubilatio, vol. 1, Santiago de Compostela, Universidade, 1987, pp. 83-99.

Rodríguez González, A.: Livro do Concello de Pontevedra (1431-1463), Pontevedra, Museo de Pontevedra, 1989.

- Libro do Concello de Santiago (1416-1422), Santiago de Compostela, Consello da Cultura Galega, 1992.

- e J. Armas Castro: Minutario notarial de Pontevedra (1433-1435), Santiago de Compostela, Consello da Cultura Galega, 1992.

Sánchez Chouza, J. M.: A Coruña en la Baja Edad Media, Sada (A Coruña), Ediciós do Castro, 2005.

VÁZQUeZ BerTOMEU, M.: Notarios, notarías y documentos en Santiago y su Tierra en el siglo XV, Sada (A Coruña), Ediciós do Castro. 2001.

Vedía y Goossens, E.: Historia y descripción de la ciudad de La Coruña, A Coruña, Imprenta de Domingo Puga, 1975 [1845]. Edición facsimilar. 

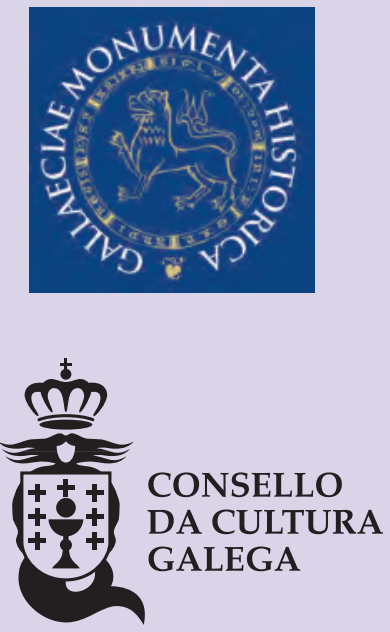